\title{
Differences Between Pediatric and Adult T Cell Responses to In Vitro Staphylococcal Enterotoxin B Stimulation
}

\begin{abstract}
Mark E. Rudolph ${ }^{1,2 *}$, Monica A. McArthur 1,3 , Robin S. Barnes ${ }^{1}$, Laurence S. Magder, Wilbur H. Chen ${ }^{1,5}$ and Marcelo B. Sztein ${ }^{1,2,3,5 *}$

${ }^{1}$ Center for Vaccine Development, University of Maryland School of Medicine, Baltimore, MD, United States, ${ }^{2}$ Molecular Microbiology and Immunology Department, University of Maryland Graduate Program in Life Sciences, Baltimore, MD, United States, ${ }^{3}$ Department of Pediatrics, University of Maryland School of Medicine, Baltimore, MD, United States, ${ }^{4}$ Epidemiology and Public Health, University of Maryland School of Medicine, Baltimore, MD, United States, ${ }^{5}$ Department of Medicine, University of Maryland School of Medicine, Baltimore, MD, United States
\end{abstract}

Toxic shock syndrome (TSS) is capable of inducing life-threatening fever, rash, and systemic organ failure, though the specific mechanisms behind these symptoms remain poorly understood. Staphylococcal enterotoxin B (SEB) and other superantigens have shown to be important factors in TSS, capable of promoting cross-linking between $T$ cell receptors and major histocompatibility complexes which results in overwhelming $T$ cell activation, proliferation, and cytokine production. The resulting proinflammatory cytokine cascade, often referred to as the "cytokine storm," seems to be critical to the development of disease. Interestingly, clinical studies have shown that children exhibit less severe TSSassociated morbidity than adults, though the mechanism behind this phenomenon has not been addressed. Indeed, despite the fact that most novel antigen exposure occurs early in life, be it from environmentally acquired pathogens or routine vaccination, normal pediatric $T$ cell immune functions remain critically underexplored. This is largely due to difficulty in obtaining enough samples to explore more than a narrow sliver of the cell-mediated immune compartment. To address this limitation, we optimized a $T$ effector $\left(T_{\text {eff }}\right) /$ circulating T follicular helper ( $\mathrm{CT}_{\mathrm{FH}}$ ) cell mass cytometry panel which allowed us to analyze a wide array of T cell populations and effector functions following in vitro SEB stimulation. We show that T cell activation - as measured by CD69 expression-following SEB stimulation is lower in pediatric participants, increasing throughout childhood, and reaching adult levels by around 15 years old. Further, while individual $\mathrm{CD}^{+}{ }^{+}$effector memory $T$ cell $\left(T_{E M}\right)$ effector molecules show limited age-associated differences following SEB stimulation, multifunctional CD4+ $T_{E M}$ are shown to positively correlate with increasing age through adolescence. Individual $\mathrm{CD}^{+} \mathrm{T}_{\mathrm{EM}}$ effectors and multifunctional phenotypes also show very strong age-associated increases following SEB stimulation. SEB stimulation has little impact on $\mathrm{CT}_{\mathrm{FH}}$ activation or functional cellular markers, regardless of age. These results, coupled with the fact that a robust proinflammatory cytokine response seems critical to developing severe TSS, suggest a possible connection between the significantly reduced $T$ cell activation and multifunctional populations following in vitro SEB stimulation in our pediatric participants and clinical observations relating to reduced TSS mortality in children.

Keywords: pediatric immunology, T cell response, staphylococcal enterotoxin B, toxic shock syndrome, multifunctionality, mass cytometry, dimensionality reduction 


\section{INTRODUCTION}

Superantigens are molecules produced by viral and bacterial pathogens which are capable of inducing massive non-specific, polyclonal $\mathrm{T}$ cell activation and effector molecule release. They accomplish this by bypassing canonical antigen processing and directly linking multiple major histocompatibility complex (MHC) class II molecules to the T cell receptor (TCR)- $\beta$ subunit outside of the traditional antigen binding groove (1). Further, superantigens bind the costimulatory $\mathrm{CD} 28$ homodimer at the immunological synapse, thus providing a second signal, necessary to drive robust $\mathrm{T}$ cell proliferation, activation, and effector molecule production (2). The resulting non-clonal specific inflammatory $\mathrm{T}$ cell responses can activate more than $20 \%$ of the peripheral $\mathrm{T}$ cell population (1-4). Further, the induced proinflammatory response leads to the recruitment and expansion of a variety of lymphocytes, including innate immune cells such as macrophages and neutrophils. These innate immune cells contribute to the proinflammatory milieu while also providing the system with additional MHC through which superantigen can bind to and activate more TCRs (3). Staphylococcal enterotoxin B (SEB) is known to be associated with food poisoning (preformed staphylococcal enterotoxin ingestion) and non-menstrual toxic shock syndrome (TSS), including soft-tissue associated infections (4). TSS is a severe, sometimes fatal disease that results from the so called "cytokine storm" which follows superantigen TCR/MHC cross-linking; however, the mechanism by which SEB induces TSS is not fully understood. Proinflammatory cytokines are known to be important to TSS pathogenesis, and SEB stimulation of $\mathrm{T}$ cells can induce the expression of multiple $\mathrm{CD} 4^{+}$and $\mathrm{CD} 8^{+}$ $\mathrm{T}_{\mathrm{EM}}$-associated effector molecules, including tumor necrosis factor (TNF)- $\alpha$, interleukin (IL)-2, IL-17A, interferon (IFN)- $\gamma$, macrophage inflammatory protein (MIP)-1 $\beta$, the degranulation marker CD107a, and Granzyme B (3-6). Interestingly, TSS-associated mortality has been shown to be less severe in children than in adults (7), but the mechanism of this observed attenuated phenotype has remained unexplored.

Healthy pediatric immune responses are difficult to study, due mostly to limited sample accessibility. However, because many pathogens, as well as vaccinations, are encountered early in life, it is critically important to better understand pediatric and adolescent $\mathrm{T}$ cell responses. Limited data have shown notable $\mathrm{T}$ cell population differences and similarities between adults and children. In general, the percentage of total $\mathrm{T}$ cells $\left(\mathrm{CD}^{+}\right.$ lymphocytes) and $\mathrm{CD}^{+} \mathrm{T}$ cells among peripheral blood mononuclear cells (PBMC) remain fairly constant from childhood into adulthood, while the percentage of $\mathrm{CD} 4^{+} \mathrm{T}$ cell increases throughout life $(8,9)$. Observations of memory $\mathrm{T}$ cell populations show higher naive $\mathrm{T}$ cell proportions in children, with memory $T$ cell phenotypes increasing into and through adulthood (9-11). Further, TCR- $\beta$ repertoire diversity decreases as individuals age (12). Most research on pediatric $\mathrm{T}$ cell effector function is limited to observing responses to vaccination against common viral pathogens. Data that have been collected show a few age-related differences among individual effector cytokine responses, but no over-arching age-associated patterns have emerged (13-15). It has been shown, however, that vaccination of younger children is less likely to induce lasting protective cell-mediated immune (CMI) functions, including $\mathrm{T}$ follicular helper (TFH) responses, than in older children and adults $(16,17)$. Interestingly, in a study that included twelve healthy pediatric participants between the ages of 7 and 17 years old, mitogen-activated $\mathrm{CD} 8^{+} \mathrm{T}_{\mathrm{EM}}$ cell multifunctionality was observed to be less robust in children than in adults (18).

Multifunctional $\mathrm{T}$ cells are defined as individual $\mathrm{T}$ cells which simultaneously exhibit multiple effector functions, such as degranulation, as well as the production of cytokines/ chemokines. Multifunctionality has been observed in memory $\mathrm{CD}^{+}$and $\mathrm{CD}^{+}{ }^{+} \mathrm{T}$ cells following stimulation with their $\operatorname{cog}^{-}$ nate antigen, as well as after superantigen stimulation. Effector expression can vary within multifunctional $\mathrm{T}$ cells, but previous work from our group has shown a robust IL-2, IFN- $\gamma$, and TNF- $\alpha$ triple-positive phenotype within CD8 effector memory T cells following SEB stimulation in adult PBMC (6). Multifunctional $\mathrm{CD}^{+}$and $\mathrm{CD} 8^{+} \mathrm{T}$ cells are important in controlling a variety of viral and bacterial pathogens (19-22). Additionally, there are data that suggest that multifunctional $\mathrm{T}$ cells are more frequently observed in the elderly following SEB stimulation, compared with younger adults (23). However, beyond preliminary data from our group (18), as far as we know, there are no reports that have evaluated in great detail multifunctional $\mathrm{T}$ cell immune responses in children.

To better explore differences between pediatric and adult multifunctional $T$ cell responsiveness, we utilized an in vitro SEB stimulation protocol and analyzed the responses by multiparameter mass cytometry. Our mass cytometry panel was developed to enable us to observe T cell populations, memory, activation, and proliferation status, as well as production of multiple cytokines/ chemokines. Here, we describe how age-associated differences in $\mathrm{T}$ cell multifunctionality and disparities among how various $\mathrm{T}$ cell subsets respond to SEB stimulation may play a role in the previously reported disparity of TSS clinical outcome between children and adults, and more generally how these differences may prove critical to any future pediatric vaccination and treatment strategies.

\section{MATERIALS AND METHODS}

\section{Participants and Isolation of PBMC}

Peripheral blood mononuclear cells were collected from 20 healthy pediatric (6-17 years of age at the time of enrollment) and 14 healthy adult (20-65 years of age at the time of enrollment) volunteers, being recruited from the Baltimore-Washington area and the University of Maryland at Baltimore campus. These studies were approved by the University of Maryland at Baltimore Institutional Review Board and were carried out in accordance with the Declaration of Helsinki. Written informed consent was obtained from all adult participants, as well as written assent and informed consent from the parents of any participant under the age of 18 years old-and assent from the pediatric participants themselves-prior to the conduct of any study procedures. PBMC were isolated immediately following blood collection, by density 
gradient centrifugation, and were then stored in liquid nitrogen following standard cryopreservation techniques $(24,25)$, until ready for use.

\section{In Vitro Stimulation}

Peripheral blood mononuclear cell were thawed and rested overnight at $37^{\circ} \mathrm{C}, 5 \% \mathrm{CO}_{2}$ in RPMI 1640 media (Gibco, Carlsbad, CA, USA), supplemented with $100 \mathrm{U} / \mathrm{mL}$ penicillin (Sigma), $100 \mu \mathrm{g} / \mathrm{mL}$ streptomycin (Sigma, St. Louis, MO, USA), $50 \mu \mathrm{g} /$ $\mathrm{mL}$ gentamicin (Gibco), 2 mM L-glutamine (Gibco), $2.5 \mathrm{mM}$ sodium pyruvate (Gibco), $10 \mathrm{mM}$ HEPES buffer (Gibco), nonessential amino acids (Lonza, Basel, Switzerland), and 10\% fetal bovine serum (Gemini Bioproducts, West Sacramento, CA, USA) to make complete RPMI (cRPMI). After overnight rest, cells were washed and resuspended in CRPMI at a concentration of $1 \times 10^{6}$ cells $/ 500 \mu \mathrm{L}$ in $5 \mathrm{~mL}$ in cell culture tubes and incubated with SEB (Toxin Technology, Sarasota, FL, USA) at $10 \mu \mathrm{g} / \mathrm{mL}$ and $3 \mu \mathrm{l} / \mathrm{mL}$ anti-CD107a monoclonal antibody ( $\mathrm{mAb}$ ) conjugated to $151 \mathrm{Eu}$ (Fluidigm, South San Francisco, CA, USA) for $2 \mathrm{~h}$ at $37^{\circ} \mathrm{C}$ in $5 \% \mathrm{CO}_{2}$. Media (cRPMI with $3 \mu \mathrm{l} / \mathrm{mL}$ anti-CD107a-151Eu $\mathrm{mAb}$ ) was used as a negative control. After the 2 -h incubation,
GolgiStop (containing monensin) and GolgiPlug (containing brefeldin A) from BD (San Jose, CA, USA) were added at $0.5 \mu \mathrm{l} / \mathrm{mL}$ to all tubes and cultures were maintained at $37^{\circ} \mathrm{C}$ in $5 \% \mathrm{CO}_{2}$ overnight.

\section{Surface and Intracellular Labeling and Mass Cytometry Analysis}

Following stimulation, PBMC were spun down and incubated with anti-CD45 (Fluidigm South San Francisco, CA, USA) mAb for barcoding. Pediatric samples were stained with CD45-154Sm and adult samples were stained with CD45-156Gd for $30 \mathrm{~min}$ at $4^{\circ} \mathrm{C}$. Cells were then washed once with flow buffer $[1 \times \mathrm{PBS}$ (Quality Biological, Gaithersburg, MD, USA), 0.1\% sodium azide (Sigma), and 2\% fetal bovine serum (Gemini Bioproducts)] and once with serum-free RPMI (Gibco) before being combined into their barcoded layout. Like-stimulated adult (CD45-156Gd) and pediatric (CD45-154Sm) PBMC were combined into a single tube for downstream staining. Mass cytometry staining was performed as described in the Materials and Methods section "Mass Cytometry Measurements" from McArthur (26) using the monoclonal antibodies listed in Table 1. In brief, cells were

TABLE 1 | Mass cytometry panel showing antibody target, stable metal isotope (or other label), antibody clone, and a brief description of the target function.

\begin{tabular}{|c|c|c|c|}
\hline Target & Stable metal isotope & Clone & Description \\
\hline CD14 & 114 Cd (Qdot) & TüK4 & Monocyte marker \\
\hline CD19 & 114 Cd (Qdot) & SJ25-C1 & B cell marker \\
\hline CXCR5 & Biotin & RF8B2 & Follicular homing chemokine receptor \\
\hline Biotin & $143 \mathrm{Nd}$ & 1D4-C5 & \\
\hline CD8 & $146 \mathrm{Nd}$ & RPA-T8 & Cytotoxic T lymphocyte marker \\
\hline $\mathrm{MIP}-1 \beta$ & $150 \mathrm{Nd}$ & $\mathrm{D} 21-1351$ & NK and monocyte recruiting chemokine \\
\hline CD107a & $151 \mathrm{Eu}$ & H4A3 & Degranulation marker \\
\hline $\mathrm{TNF}-\alpha$ & $152 \mathrm{Sm}$ & Mab11 & Proinflammatory cytokine \\
\hline CD62L & $153 \mathrm{Eu}$ & DREG-56 & Lymphoid-tissue homing selectin \\
\hline CD45 & $154 \mathrm{Sm}$ & HI30 & Pan-leukocyte barcoding marker \\
\hline $\mathrm{CD} 27$ & $155 \mathrm{Gd}$ & L128 & TNF superfamily_costimulatory molecule \\
\hline CD45 & $156 \mathrm{Gd}$ & HI30 & Pan-leukocyte barcoding marker \\
\hline $\mathrm{IL}-2$ & $158 \mathrm{Gd}$ & MQ1-17H12 & Induction of T cell differentiation and proliferation \\
\hline Ki67 & 161 Dy & B56 & Nuclear proliferation marker \\
\hline CD69 & 162 Dy & FN50 & Activation marker \\
\hline IL-17A & 164 Dy & N49-653 & Tc/h17 effector cytokine \\
\hline $\mathrm{IFN}-\gamma$ & $165 \mathrm{Ho}$ & $\mathrm{B} 27$ & Proinflammatory cytokine \\
\hline IL-10 & $166 \mathrm{Er}$ & JES3-9D7 & Anti-inflammatory cytokine \\
\hline CD154 (CD40L) & $168 \mathrm{Er}$ & $24-31$ & Costimulatory molecule; Tfh induction of B cell maturation \\
\hline CD45RA & $169 \mathrm{Tm}$ & $\mathrm{HI}-100$ & T cell memory marker \\
\hline CD3 & $170 \mathrm{Er}$ & UCHT1 & TCR coreceptor (T cell marker) \\
\hline Granzyme B & $171 \mathrm{Yb}$ & GB11 & Secreted cytotoxic effector molecule \\
\hline IL-21 & $172 \mathrm{Yb}$ & $3 \mathrm{~A} 3-\mathrm{N} 2$ & Tfh effector cytokine (germinal center formation) \\
\hline ICOS (CD278) & $173 \mathrm{Yb}$ & C398.4A & Tfh costimulatory marker (B cell help) \\
\hline CD4 & $174 \mathrm{Yb}$ & SK3 & Helper T Iymphocyte marker \\
\hline Cell I.D. (DNA) & 191/193 Ir & $\mathrm{n} / \mathrm{a}$ & DNA intercalator \\
\hline Viability & 194/195 Pt & $\mathrm{n} / \mathrm{a}$ & Viability stain \\
\hline
\end{tabular}

Primary surface antibodies are filled with blue, secondary surface antibodies with green, and intracellular antibodies with orange. Barcoding antibodies are shaded in yellow, and antiCD107a, which is added during stimulation to best account for the active cycling between the surface and intracellular vesicles, is highlighted in green. 
labeled with metal-tagged antibodies against specific surface and intracellular targets, as well as with cisplatin as a viability marker and iridium as a DNA intercalator, before being prepared and run by our flow and mass cytometry core in a CyTOF instrument (Fluidigm). Mass cytometry data were analyzed using WinList version 9.0.1 (Verity Software House, Topsham, ME, USA) following debarcoding of the files with Premium Cytobank (Cytobank, Inc., Santa Clara, CA, USA) (Figure S1 in Supplementary Material). CITRUS analyses were performed in Premium Cytobank.

\section{Statistical Analyses}

All analyses, except for CITRUS, were performed using GraphPad Prism version 7.0. Unpaired $t$-tests or Spearman's correlations were performed depending on the analysis as indicated. $p$-Values of $<0.05$ were considered significant.

\section{RESULTS}

\section{Age-Dependent Variability Among Baseline T Cell Populations}

We stained unstimulated PBMC from healthy pediatric and adult participants with metal-conjugated monoclonal antibodies followed by acquisition on a mass cytometer (Table 1). Total T cells $\left(\mathrm{CD}^{+} \mathrm{CD} 14^{-} \mathrm{CD} 19^{-}\right)$were subdivided into helper $\mathrm{T}$ cells $\left(\mathrm{T}_{\mathrm{H}}\right.$; $\left.\mathrm{CD} 4^{+} \mathrm{CD} 8^{-}\right)$and cytotoxic $\mathrm{T}$ cells $\left(\mathrm{T}_{\mathrm{C}} ; \mathrm{CD} 4^{-} \mathrm{CD} 8^{+}\right)$populations. We further used expression of CD62L and CD45RA to define $\mathrm{T}$ cell memory subsets including naive $\left(\mathrm{T}_{\mathrm{N}} ; \mathrm{CD} 2 \mathrm{~L}^{+} \mathrm{CD} 45 \mathrm{RA}^{+}\right)$, central memory $\left(\mathrm{T}_{\mathrm{CM}} ; \mathrm{CD} 62 \mathrm{~L}^{+} \mathrm{CD} 45 \mathrm{RA}^{-}\right)$, effector memory $\left(\mathrm{T}_{\mathrm{EM}} ; \mathrm{CD} 2 \mathrm{~L}^{-} \mathrm{CD} 45 \mathrm{RA}^{-}\right.$), and effector memory $\mathrm{CD}^{-}$RA ${ }^{+}$ $\left(\mathrm{T}_{\mathrm{EMRA}} ; \mathrm{CD} 2 \mathrm{~L}^{-} \mathrm{CD} 45 \mathrm{RA}^{+}\right)$. The identification of $\mathrm{T}$ memory subsets using the CD62L/CD45RA classification is an established methodology, as CD62 $\mathrm{L}^{-/ 10}$ populations map well with effector memory as defined by CCR7 (27). In order to better identify differentiated memory $\mathrm{T}$ cells, CD27 is included in our panel (28-30). T cell populations and memory subsets were compared among 6-15-year-old pediatric $(n=11), 16-17$-year-old pediatric $(n=9)$, and adult (20-65 year-old; $n=14)$ participants (Figure 1).

All 34 participants showed similar total $\mathrm{T}$ cell percentages regardless of age (Figure 1A). As previously described $(8,9)$, we observed a relationship between age and $\mathrm{T}_{H}$ with a significantly lower percentage of $\mathrm{CD}^{+} \mathrm{T}$ cells in younger pediatric participants compared to adults (Figure 1B). Although 16-17-year-old pediatric participants had a significantly higher percentage of $\mathrm{CD}^{+} \mathrm{T}$ cells than adults, the trend did not extend to the younger pediatric participants (Figure 1C). The $\mathrm{CD}^{+} \mathrm{T}_{\mathrm{N}}$ and $\mathrm{T}_{\mathrm{EM}}$ subsets differed significantly according to age (and trended among $\mathrm{CD} 4^{+}$) with younger participants demonstrating a higher percentage of $\mathrm{T}_{\mathrm{N}}$ and a lower percentage of $\mathrm{T}_{\mathrm{EM}}$ (Figures 1D,E). However, $\mathrm{T}_{\mathrm{CM}}$ and $\mathrm{T}_{\mathrm{EMRA}}$ did not show any significant age-dependent trends in either $\mathrm{CD} 4^{+}$or $\mathrm{CD}^{+}$ populations (Figures 1D,E). Furthermore, when we graphed percent memory subsets as a function of age, $\mathrm{T}_{\mathrm{N}}$ cells consistently decreased with age while $\mathrm{T}_{\mathrm{EM}}$ consistently increased with age (Figures S2A,B in Supplementary Material).

\section{T Cell Activation Following SEB Stimulation Increases Throughout Childhood}

We used CD69 expression to define activated $\mathrm{T}$ cell populations following SEB stimulation. To calculate net expression, we subtracted the percentages of $\mathrm{CD} 9^{+}$cells in media controls from the percentages of $\mathrm{CD} 69^{+}$cells in SEB-stimulated cultures. Net activation of $\mathrm{CD}^{+} \mathrm{T}$ cells was significantly lower in younger pediatric participants than in older pediatric participants; however, there were no significant differences between the pediatric age groups and the adult participants (Figure 2A). When we focused on net activation following SEB stimulation as a function of age within the pediatric participants, there was a significant increase of net CD69 expression to approximately $25 \%$ of $\mathrm{CD} 4^{+}$ $\mathrm{T}$ cells (Figure 2B). In contrast, SEB-induced CD69 expression remained consistent throughout adulthood (Figure 2C). $\mathrm{CD}^{+} \mathrm{T}$ cells demonstrated significant increases in net CD69 expression among both pediatric age strata compared to adults (Figure 2D) and as a function of aging throughout childhood (Figure 2E). As with activated $\mathrm{CD} 4^{+} \mathrm{T}$ cells, net activation of $\mathrm{CD}^{+} \mathrm{T}$ cells by SEB stimulation reached adult levels $(\sim 25 \%)$ by around the age of 15 years and are maintained throughout adulthood (Figure 2F).

\section{SEB Stimulated CD4 ${ }^{+} T_{E M}$ Show Increased Functionality Throughout Childhood}

To explore the functionality of $\mathrm{CD}^{+} \mathrm{T}_{\mathrm{EM}}$, we first determined the percent net expression of effector molecules MIP-1 $\beta$, CD107a, TNF- $\alpha$, IL-2, IL-17A, IFN- $\gamma$, and Granzyme B following SEB stimulation (Figure 3A). Of these effector functions, IFN- $\gamma$ demonstrated a strongly significant age-dependence with lower levels of net IFN- $\gamma$ expression in younger pediatric participants than both the older pediatric and adult participants. IL-17A also trended toward an age-dependent increase in net expression following SEB stimulation but did not reach statistical significance $(p=0.07)$. Interestingly, older pediatric participants showed significantly greater TNF- $\alpha$ and IFN- $\gamma$ expression than adults, as well as lower CD107a expression than adults and younger children.

We used theFCOM ${ }^{\mathrm{TM}}$ feature of WinList version 9.0.1 to explore all possible combinations of the seven aforementioned biomarkers. These results were used to tabulate the percentages of $\mathrm{CD}^{+}$ $\mathrm{T}_{\mathrm{EM}}$ that expressed $1,2,3$, or $>3$ of the measured effector functions to determine whether increased functionality is impacted by age. Similar to our previous age-dependent observations of $\mathrm{CD}^{+} \mathrm{T}_{\mathrm{EM}}$ activation by net CD69 expression, the net functionality of $\mathrm{CD} 4^{+}$ $\mathrm{T}_{\mathrm{EM}}$, as characterized by MIP- $1 \beta$, CD107a, TNF- $\alpha$, IL-2, IL-17A, IFN- $\gamma$, and Granzyme B, was lower in younger children, but increased to adult levels by $\sim 15$ years (Figures $3 B-I$ ). The CD $4^{+}$ $\mathrm{T}_{\mathrm{EM}}$ expressing a single measured effector function showed an increase from the age of 6-17 that approached statistical significance $(p=0.053)$ (Figure 3B), whereas $\mathrm{CD}^{+} \mathrm{T}_{\mathrm{EM}}$ expressing 2, 3, or $>3$ effector functions all showed direct, significant correlations between increasing age through adolescence and multifunctional responses (Figures 3D,F,H). In contrast, in adults, net functional responses did not correlate with increasing age, maintaining similar levels from 20 to 65 years of age (Figures 3C,E,G,I). 

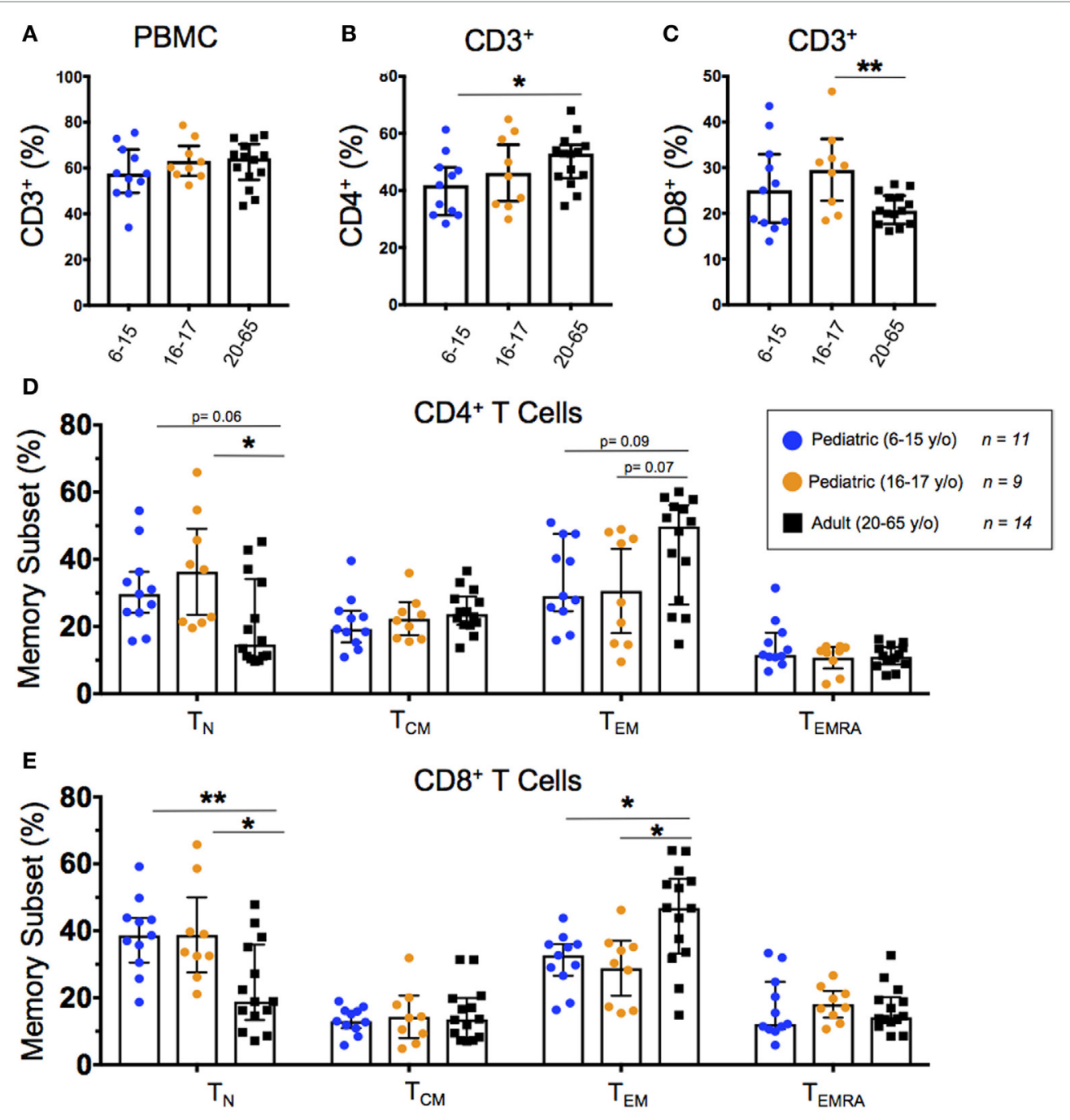

FIGURE 1 | Baseline $T$ cell populations. Scatter plots showing the percentages of (A) baseline $\mathrm{CD}^{+} \mathrm{T}$ cells, (B) $\mathrm{CD} 3^{+} \mathrm{CD} 4^{+}$helper $\mathrm{T}$ cells, and $(\mathbf{C}) \mathrm{CD} 3^{+} \mathrm{CD} 8^{+}$ cytotoxic $T$ cells, as well as (D) CD4+ and (E) CD8 naive (CD45RA+CD62 $\left.\mathrm{L}^{+}\right)$, T central memory $\left(\mathrm{T}_{\mathrm{CM}}\right.$; CD45RA-CD62 $\left.\mathrm{L}^{+}\right)$, effector memory (CD45RA-CD62 $\left.\mathrm{L}^{-}\right)$, and EMRA (CD45RA $\left.{ }^{+} \mathrm{CD} 2 \mathrm{~L}^{-}\right)$populations among 6-15-year-old pediatric $(n=11), 16-17$-year-old pediatric $(n=9)$, and adult $(n=14)$ participants (media). Bars represent medians with whiskers indicating interquartile ranges. Statistics were analyzed by unpaired $t$-test $\left({ }^{*} p<0.05 ;{ }^{* *} p<0.01\right)$.

\section{SEB Stimulated CD8 ${ }^{+} T_{\text {EM }}$ Effector Responses and Functionality Increase Significantly Throughout Childhood}

To analyze the functionality of $\mathrm{CD}^{+} \mathrm{T}_{\mathrm{EM}}$, we again looked at the percent net expression of effector molecules MIP-1 $\beta$, CD107a, TNF- $\alpha$, IL-2, IL-17A, IFN- $\gamma$, and Granzyme B following SEB stimulation (Figure 4A). In contrast to the majority of the $\mathrm{CD}^{+}$ $\mathrm{T}_{\mathrm{EM}}$ effector responses, $\mathrm{CD}^{+} \mathrm{T}_{\mathrm{EM}}$ net MIP-1 $\beta$, CD107a, and IL-2 expression, in addition to IFN- $\gamma$ expression, were significantly higher in adults than in younger participants following SEB stimulation. Further, while the net effector responses between the older pediatric (16-17 years old) and adult participants differed less, significant age dependence was seen with IL-2 expression.

We again used FCOM ${ }^{\mathrm{TM}}$ to explore percentages of $\mathrm{CD}^{+} \mathrm{T}_{\mathrm{EM}}$ that expressed $1,2,3$, or $>3$ of the measured effector functions to determine whether increased functionality correlated with age.
$\mathrm{CD}^{+} \mathrm{T}_{\mathrm{EM}}$ expressing $1,2,3$, or $>3$ of the measured effector functions all showed direct significant correlations between increasing age through adolescence and percent net functionality, with the most significant correlations demonstrated by the populations expressing $>1$ effector function (Figures $4 \mathbf{B}, \mathbf{D}, \mathbf{F}, \mathbf{H}$ ). Similar to $\mathrm{CD} 4^{+} \mathrm{T}_{\mathrm{EM}}$, the adult net functional $\mathrm{CD}^{+} \mathrm{T}_{\mathrm{EM}}$ responses showed no correlation between age and functionality and maintained similar levels from 20 to 65 years of age (Figures 4C,E,G,I).

\section{Gender Is Not Associated With Major Differences in CD4 ${ }^{+}$and CD8 ${ }^{+} \mathrm{T}_{\mathrm{EM}}$ Effector Responses and Functionality Following SEB Stimulation}

To explore whether gender may play a role in the previously observed heterogeneous responses to SEB, we compared CD4 ${ }^{+}$ and $\mathrm{CD}^{+} \mathrm{T}_{\mathrm{EM}}$ effector responses between male and female 


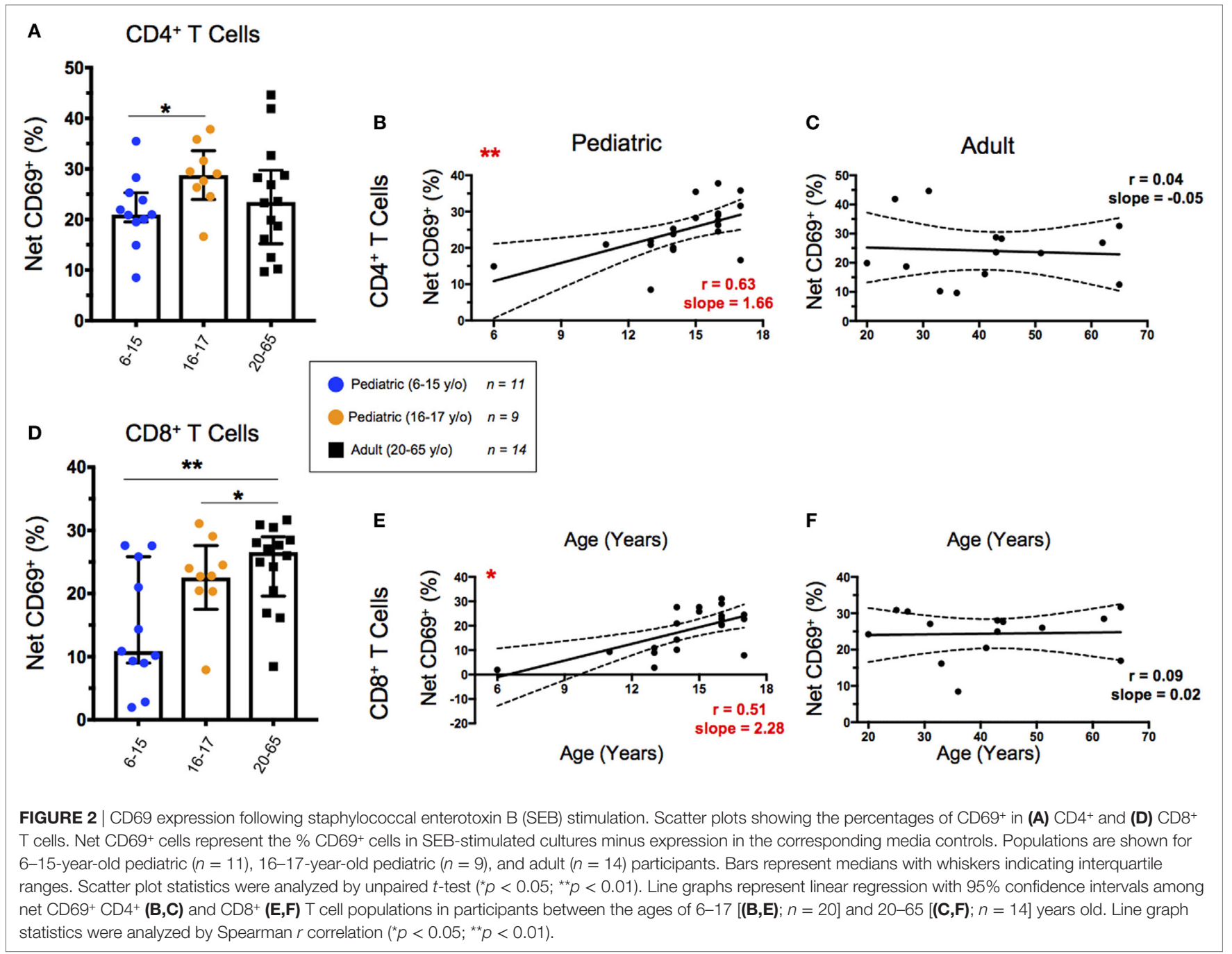

participants. As our two youngest pediatric participants were both male (ages 6 and 11, respectively) and likely prepubescent, we excluded them from these analyses. We further performed gender comparisons between like-age groups to avoid confounding gender- and age-associated heterogeneity. Pediatric males had higher net $\mathrm{CD} 4{ }^{+} \mathrm{T}_{\mathrm{EM}}$ expression of TNF- $\alpha$, IL- 2 , and IFN- $\gamma$ than pediatric females (Figure S3A in Supplementary Material). However, there were no significant gender-associated differences in $\mathrm{CD}^{+} \mathrm{T}_{\mathrm{EM}}$ expressing 1,2,3, or $>3$ effector functions in the pediatric participants (Figure S3B in Supplementary Material). Of interest, there were no significant gender-associated differences in the $\mathrm{CD} 4^{+} \mathrm{T}_{\mathrm{EM}}$ effector functionality among the adult participants (Figures S3C,D in Supplementary Material). While pediatric males demonstrated significantly higher net $\mathrm{CD} 8^{+} \mathrm{T}_{\mathrm{EM}}$ IFN- $\gamma$ expression than pediatric females, there were no significant gender-associated differences in $\mathrm{CD}^{+} \mathrm{T}_{\mathrm{EM}}$ expressing $1,2,3$, or $>3$ effector functions in the pediatric participants (Figures S3E,F in Supplementary Material). Similar to $\mathrm{CD}^{+} \mathrm{T}_{\mathrm{EM}}$, there were no significant gender-associated differences in $\mathrm{CD}^{+} \mathrm{T}_{\mathrm{EM}}$ effector functionality among the adult participants (Figures S3G,H in Supplementary Material).

\section{Circulating $\mathrm{T}_{\mathrm{FH}}$ Populations and Functions Show Variability Across Ages}

The percentages of circulating $\mathrm{T}_{\mathrm{FH}}$ cells $\left(\mathrm{cT}_{\mathrm{FH}}\right)$, defined by CXCR5 expression on $\mathrm{CD}^{+} \mathrm{T}$ cells, did not change significantly throughout childhood (Figure 5A). However, $\mathrm{c}_{\mathrm{FH}}$ percentages peaked in early adulthood and decreased slightly throughout aging (Figure 5B). Interestingly, aging correlated strongly with an increase in the percentage of effector $\mathrm{cT}_{\mathrm{FH}}\left(\mathrm{CD} 4{ }^{+} \mathrm{CXCR}^{+} \mathrm{CD} 27^{+} \mathrm{CD} 45 \mathrm{RA}^{-}\right)$among total $\mathrm{cT}_{\mathrm{FH}}$ (Figure $5 \mathrm{C}$ ). Effector $\mathrm{CT}_{\mathrm{FH}}$ are a subset of the total $\mathrm{cT}_{\mathrm{FH}}$ population, and have shown to expand, as well as produce more of IL-21, in an antigen-specific manner following vaccination (31). There were no significant differences in $\mathrm{cT}_{\mathrm{FH}}$ percentages between unstimulated and SEB stimulated conditions; however, younger and older pediatric participants had a significantly lower percentage of effector $\mathrm{CT}_{\mathrm{FH}}$ than did adults under both unstimulated and SEB-stimulated conditions (Figure 5D). To address age-related differences between expression functional $\mathrm{cT}_{\mathrm{FH}}$ markers, we explored IL-21, IL-2, CD154 (also known as CD40 ligand), ICOS (CD278), and TNF- $\alpha$. $\mathrm{T}_{\mathrm{FH}}$ expression of IL-21 and IL-2 play important roles in B cell maturation and isotype 

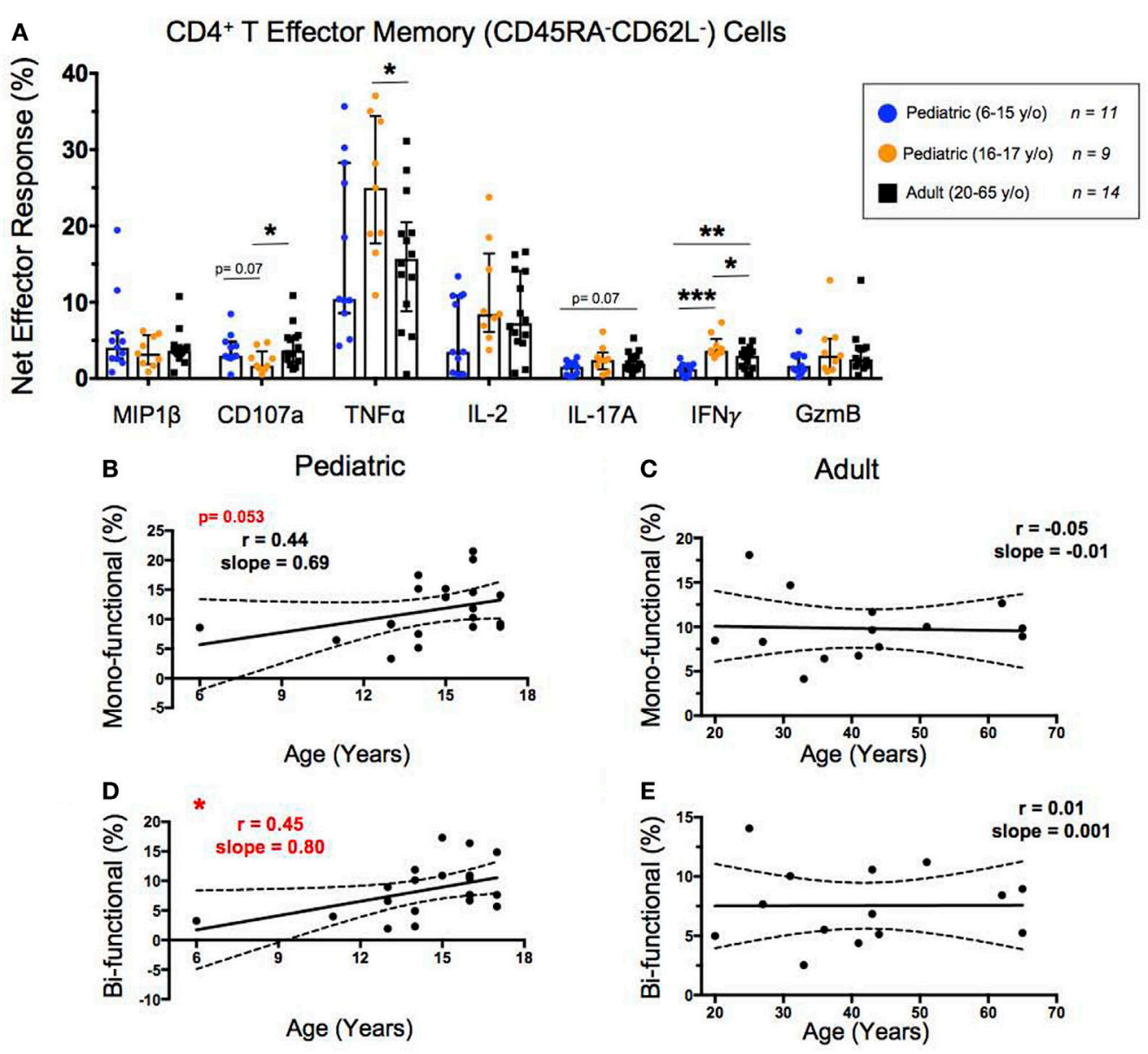

$\mathbf{F}$

Pediatric
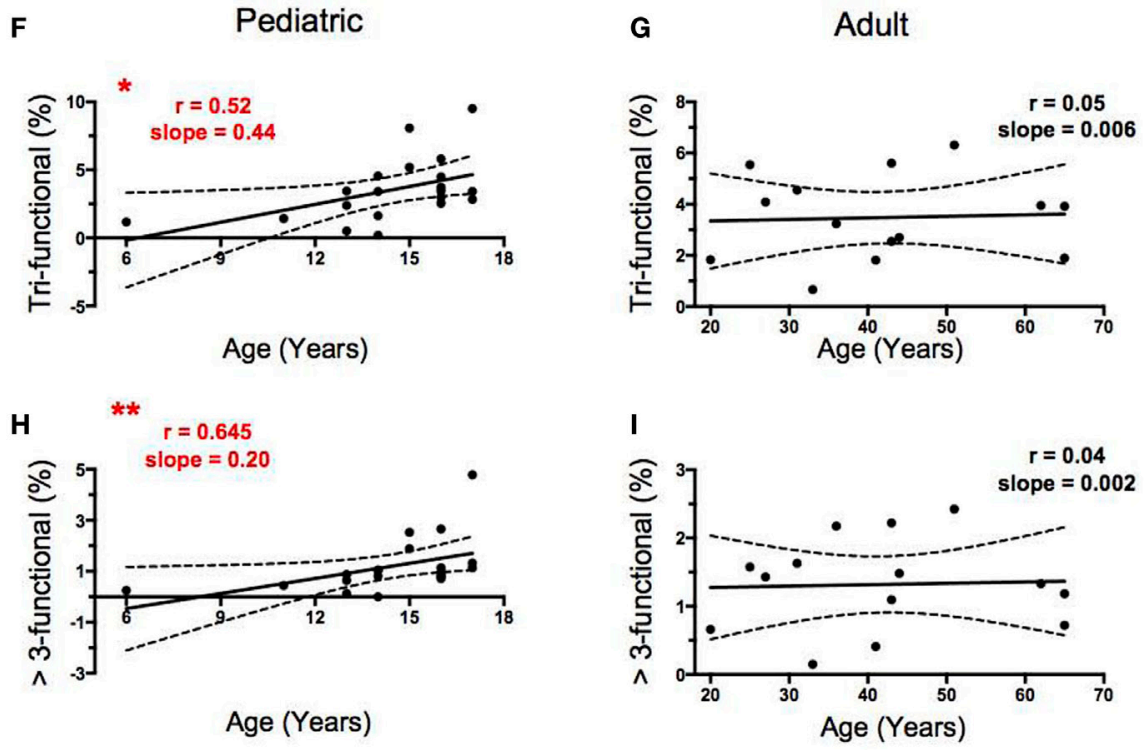

FIGURE $3 \mid$ CD4+ T effector memory response. (A) Scatter plot showing the net percentages of CD4+ $T_{E M}$ producing MIP-1 $\beta$, CD107a, TNF- $\alpha$, IL-2, IL-17A, IFN- $\gamma$, and ${ }^{* \star *}$ Granzyme B (GzmB) following SEB stimulation. Results are shown for the following populations: 6-15-year-old pediatric $(n=11)$, 16-17-year-old pediatric $(n=9)$, and adult $(n=14)$ participants. Bars represent medians with whiskers indicating interquartile ranges. Scatter plot statistics were analyzed by unpaired $t$-test $\left({ }^{\star} p<0.05 ;{ }^{* \star} p<0.01 ;{ }^{\star \star} p<0.001\right)$. Line graphs represent linear regression with 95\% confidence intervals among CD4+ $T$ effector memory cell mono- (B,C), bi- $(\mathbf{D}, \mathbf{E})$, tri- (F,G), and >3- (H,I) functional populations following SEB stimulation within participants between the ages of $6-17(n=20)$ and $20-65(n=14)$ years old. Line graph statistics were analyzed by Spearman $r$ correlation $\left({ }^{*} p<0.05 ;{ }^{* \star} p<0.01\right)$. 

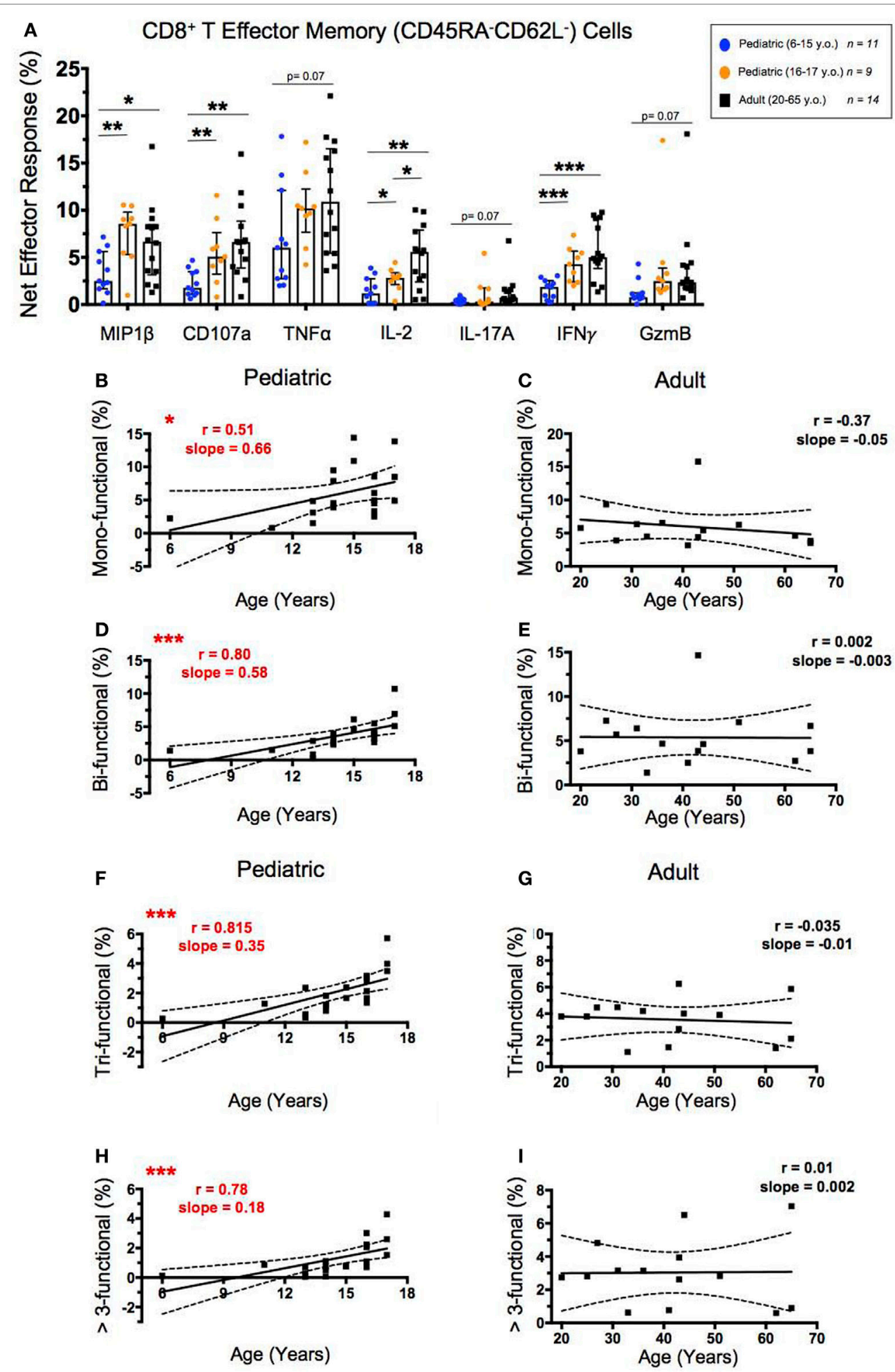

FIGURE 4 | CD8 ${ }^{+}$T effector memory response. (A) Scatter plot showing the net percentages of CD8 ${ }^{+} \mathrm{T}_{\mathrm{EM}}$ Producing MIP-1 $\beta$, CD107a, TNF- $\alpha$, IL-2, IL-17A, IFN- $\gamma$, and Granzyme B (GzmB) following SEB stimulation. Results are shown for the following populations: 6-15-year-old pediatric $(n=11)$, 16-17-year-old pediatric $(n=9)$, and adult $(n=14)$ participants. Bars represent medians with whiskers indicating interquartile ranges. Scatter plot statistics were analyzed by unpaired $t$-test $\left({ }^{*} p<0.05 ;{ }^{* *} p<0.01 ;{ }^{* *} p<0.001\right)$. Line graphs represent linear regression with 95\% confidence intervals among CD8 ${ }^{+} \mathrm{T}$ effector memory cell mono- (B,C), bi- (D,E), tri- (F,G), and >3- $(\mathbf{H}, \mathbf{I})$ functional populations following SEB stimulation within participants between the ages of $6-17(n=20)$ and $20-65(n=14)$ years old. Line graph statistics were analyzed by Spearman $r$ correlation $\left({ }^{*} p<0.05 ;{ }^{\star \star \star} p<0.001\right)$. 

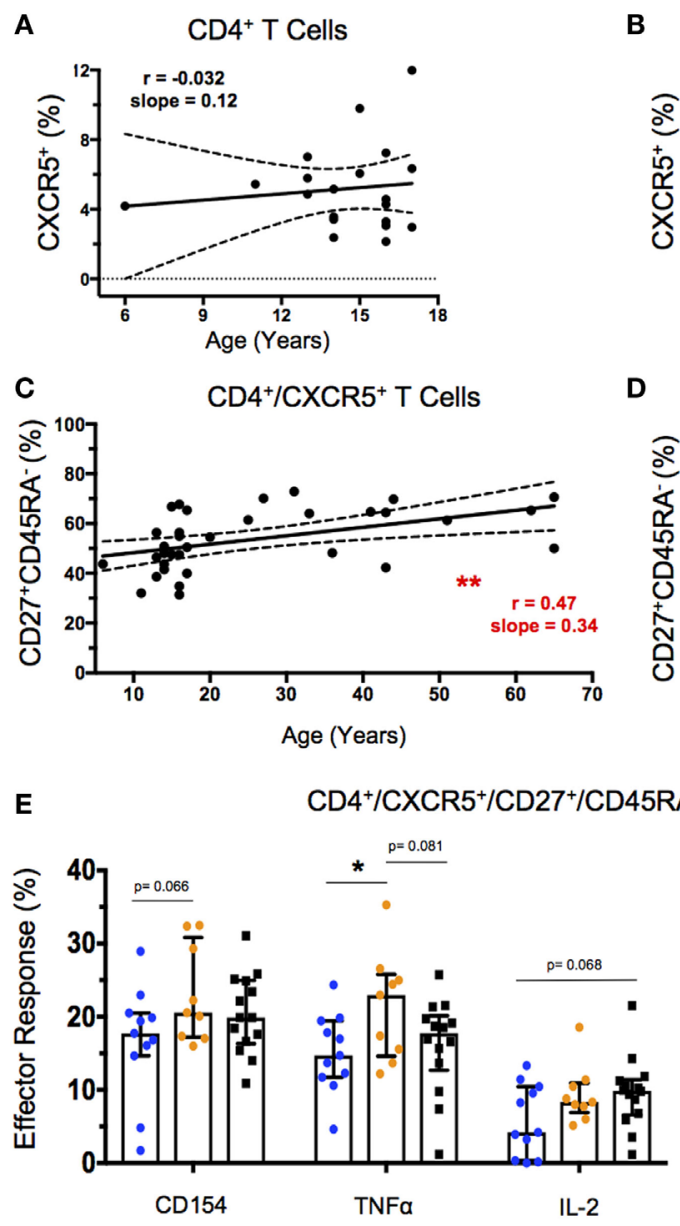

B
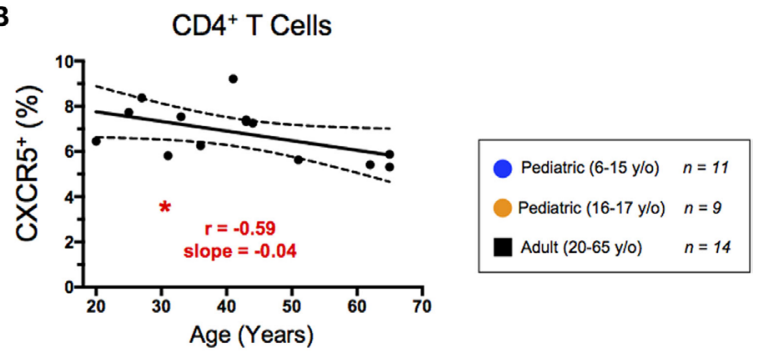

D

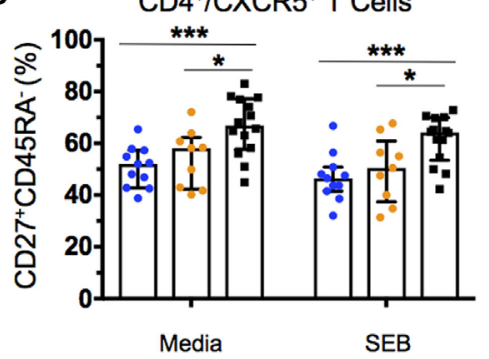

FIGURE 5 | Circulating T follicular helper $\left(\mathrm{C}_{\mathrm{FH}}\right)$ cell response. (A,B) Line graphs represent linear regression with 95\% confidence intervals among baseline CD4 ${ }^{+}$CXCR5 ${ }^{+}$T cells in children between 6 and 17 years old $(n=20)$ and adults between 20 and 65 years old $(n=14)$. (C) Line graph represents linear regression with 95\% confidence intervals among CD4+CXCR5 ${ }^{+}$CD27+CD45RA- effector $\mathrm{CT}_{\mathrm{FH}}$ in all volunteers $(n=34)$ between 6 and 65 years old. Line graph statistics were analyzed by Spearman $r$ correlation $\left({ }^{\star} p<0.05\right.$; $\left.{ }^{\star \star} p<0.01\right)$. (D) Scatter plots showing percent effector $c T_{F H}$ under both unstimulated (media) and SEB stimulated conditions. (E) Scatter plots showing net percentages of effector CT FH producing CD154 (CD40L), TNF- $\alpha$, IL-2, ICOS, and IL-21. Populations are shown for 6-15-year-old pediatric $(n=11), 16-17$-year-old pediatric $(n=9)$ and adult $(n=14)$ participants. Bars represent medians with whiskers indicating interquartile ranges. Scatter plot statistics were analyzed by unpaired $t$-test $\left({ }^{\star} p<0.05 ;{ }^{\star \star \star} p<0.001\right)$.

switching through transcriptional upregulation of BLIMP1 and AID (31). CD154 acts as a signal-two for B cell activation (32). ICOS interacts with ICOS ligand during $\mathrm{cT}_{\mathrm{FH}}$ development (32). TNF- $\alpha$-expression indicates a $\mathrm{T}_{\mathrm{H}} 1$-like $\mathrm{cT}_{\mathrm{FH}}$ phenotype, which may lead to preferential development of antibodies more capable of inducing further cytotoxicity (33). Age-associated differences in effector $\mathrm{cT}_{\mathrm{FH}}$ responses following $\mathrm{SEB}$ stimulation were less striking; however, younger pediatric participants showed significantly lower IL-21 and trending lower IL-2 expression than did adult participants (Figure 5E). Of note, higher net $\mathrm{cT}_{\mathrm{FH}}$ expression of CD154 and TNF- $\alpha$ occurred in the older pediatric participants despite the lower percentage of effector $\mathrm{cT}_{\mathrm{FH}}$ in this group compared to adults (Figures 5D,E). No significant differences have been observed in the levels of ICOS expression in effector $\mathrm{cT}_{\mathrm{FH}}$ cells between children and adults. Similarly, gender had no significant impact on effector $\mathrm{cT}_{\mathrm{FH}}$ populations or effector responses (Figures S4A-D in Supplementary Material).

\section{Unsupervised Comparison of Multifunctionality Between Age Groups}

We used the cluster identification, characterization, and regression (CITRUS) tool to identify and further analyze differences in SEB stimulated $\mathrm{CD}^{+} \mathrm{T}$ cell responses between pediatric and adult participants (34). The analyses were performed by supervised gating of $\mathrm{CD}^{+} \mathrm{CD} 69^{+} \mathrm{T}_{\mathrm{EM}}$ and $\mathrm{T}_{\mathrm{EMRA}}$ separated into adult (20-65 years old; $n=14)$ and young pediatric $(6-15$ years old; $n=11)$ participant groups. We then used CITRUS to perform unsupervised clustering based on MIP-1 $\beta$, CD107a, TNF- $\alpha$, IL-2, IL-17A, IFN- $\gamma$, and Granzyme $\mathrm{B}$ in abundance mode to distinguish cell signatures between pediatric and adult participants. We subsequently ran a predictive Nearest Shrunken Centroid (PAMR) association model with equal event sampling per file, using a minimum cluster size of $3 \%$ of the total events clustered and a cross-validation rate of 1 . 


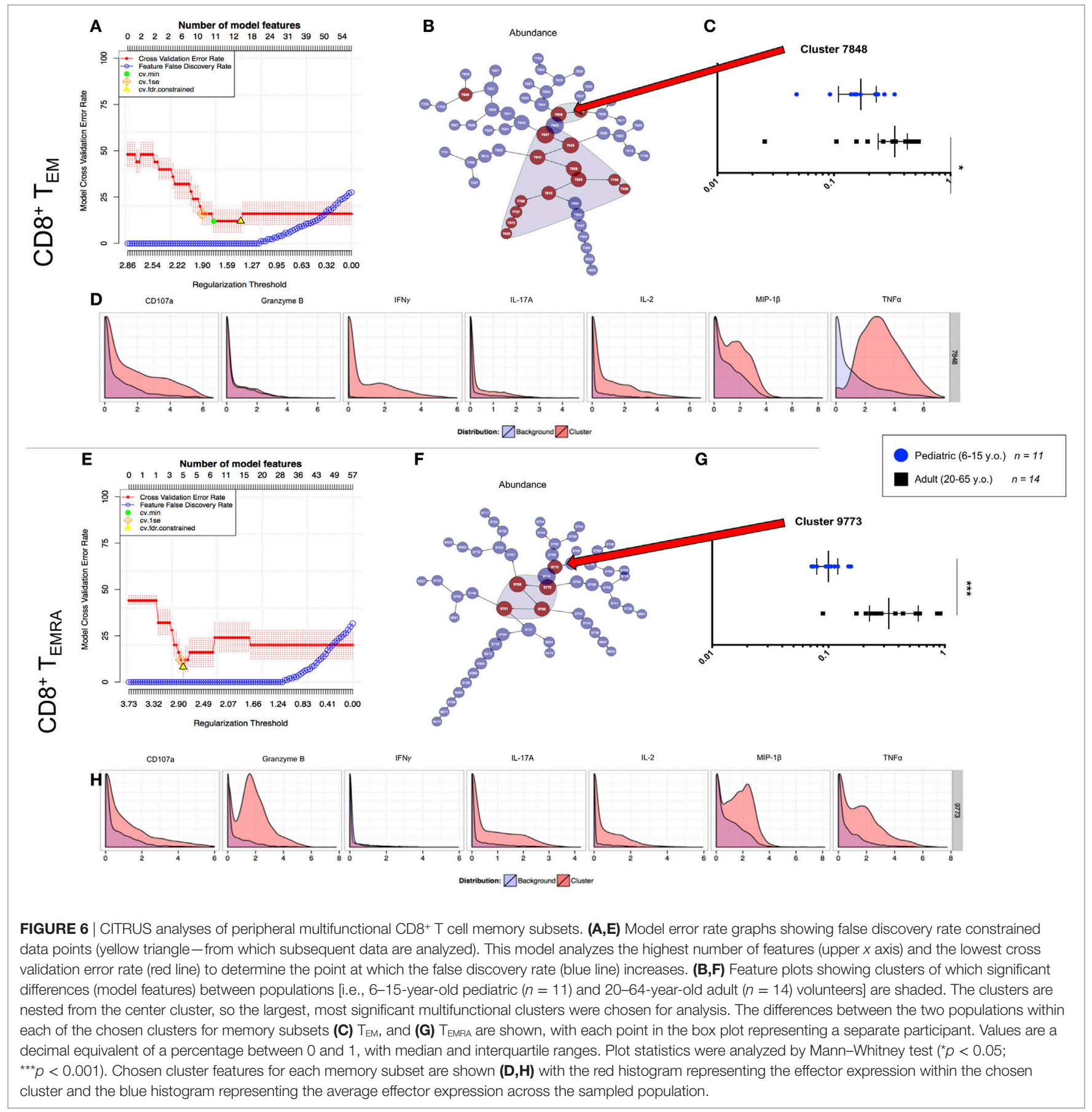

The resulting model error rate graphs for the activated $\mathrm{CD} 8^{+} \mathrm{T}_{\mathrm{EM}}$ and $\mathrm{T}_{\mathrm{EMRA}}$ analyses showed minimum cross-validation error rates below $20 \%$ and false-discovery rate constrained points with more than one model feature (Figures 6A,E). Nested clusters start with the largest, central most node, and branch into one or two child node(s), continuing until the maximum number of clusters greater than the minimum cluster size is generated. Feature plots showed clusters that were significantly different between analyzed groups (Figures 6B,F). To focus on multifunctionality, we analyzed the most multifunctional parent clusters that were significantly different between adult and pediatric groups: cluster 7848 for $\mathrm{CD}^{+}$ $\mathrm{T}_{\mathrm{EM}}$, and cluster 9773 for $\mathrm{CD} 8^{+} \mathrm{T}_{\mathrm{EMRA}}$. The chosen clusters showed significantly lower abundance among pediatric participants than among adults (Figures 6C,G). We assessed multifunctionality by analysis of the CITRUS trees colored by channel, wherein heat maps indicate the relative intensity of each clustered effector on each node (Figures S5A,B in Supplementary Material). Further, histograms generated for the chosen clusters showed a highly 
A A
Cluster (7848)

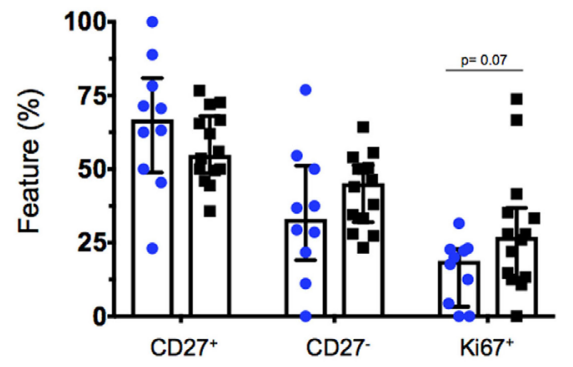

C

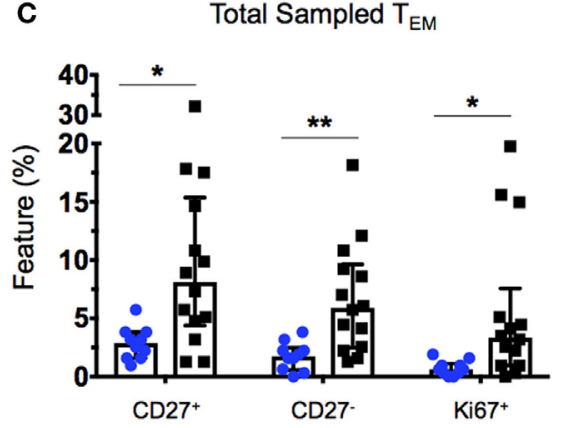

B
Pediatric (6-15 y.o.) $n=11$

Adult (20-65 y.o.) $n=14$ Cluster (9773)

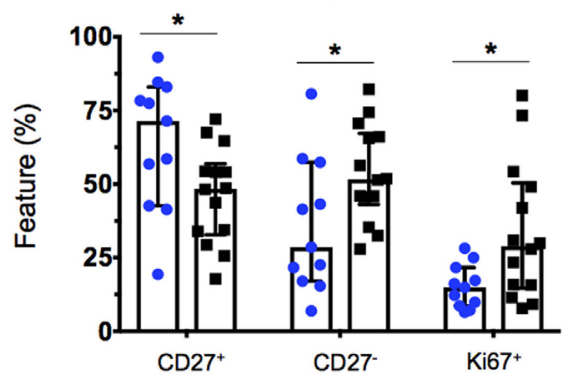

D

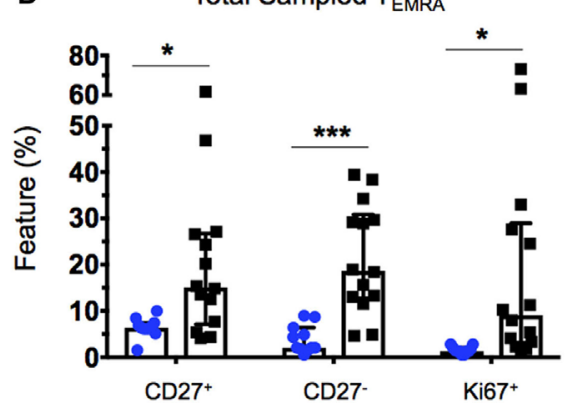

FIGURE 7 | Highly multifunctional CD8 ${ }^{+} T$ cell functional states. Scatter plots showing the percentages of highly multifunctional CD8 ${ }^{+} T$ cells as defined by $\mathrm{CITRUS}$ node isolation. (A) $\mathrm{T}_{\mathrm{EM}}$ and (B) $\mathrm{T}_{\text {EMRA }}$ cells within the chosen highly multifunctional nodes (see Figure 6) showing proportions of cytotoxic (CD27-) or proliferative

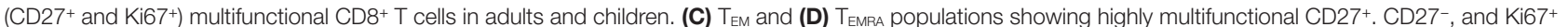
cells from within the total CITRUS sampled CD8 ${ }^{+}$memory $T$ cell subsets, exhibiting the proportion of highly multifunctional cytotoxic or proliferative phenotypes from within the each memory subset. Populations split among 6-15-year-old pediatric $(n=11)$ and adult $(n=14)$ participants. Bars represent medians with whiskers indicating interquartile ranges. Scatter plot statistics were analyzed by unpaired $t$-test $\left({ }^{*} p<0.05 ;{ }^{* *} p<0.01\right.$; and $\left.{ }^{* * *} p<0.001\right)$.

multifunctional phenotype (in red) compared to background (originating parent node) expression in blue (Figures 6D,H).

Taken together, these analyses identified highly multifunctional activated $\mathrm{CD}^{+} \mathrm{T}_{\mathrm{EM}}$ and $\mathrm{T}_{\mathrm{EMRA}}$ populations that are significantly more abundant in adults than in children. We extracted these populations for analyses in order to validate our unsupervised data analyses and further explore the characteristics of these highly multifunctional cells.

\section{Downstream Identification of Cytotoxic and Proliferative Cellular Phenotypes From Within Highly Multifunctional CD8 ${ }^{+}$ T Cell Populations}

The previously described highly multifunctional CITRUS clusters $7848\left(\mathrm{CD}^{+} \mathrm{T}_{\mathrm{EM}}\right)$ and $9773\left(\mathrm{CD}^{+} \mathrm{T}_{\mathrm{EMRA}}\right)$, were exported as individual FCS files and analyzed by supervised gating using Winlist 9.0.1 software. We used CD27 expression to characterize CD8 ${ }^{+}$ $\mathrm{T}$ cells as either generally cytotoxic and more mature $\left(\mathrm{CD} 27^{-}\right)$or generally more naive $\left(\mathrm{CD} 27^{+}\right)$phenotypes (28-30). Ki67 expression was used in this analysis to measure cell proliferation (35). We analyzed the correlation between $\mathrm{CD} 27^{+}$and $\mathrm{Ki} 67^{+}$(proliferating) $\mathrm{T}_{\mathrm{EM}}$ and $\mathrm{T}_{\mathrm{EMRA}}$ cells between pediatric and adult populations to determine whether $\mathrm{T}$ cell maturation trends varied between the groups. While $\mathrm{Ki} 67^{+}$levels are generally higher in adult $\mathrm{T}_{\mathrm{EM}}$ and $\mathrm{T}_{\mathrm{EMRA}}$, the trends between proliferation and $\mathrm{CD} 27^{+}$(more naive) cells were conserved between children and adults (Figures S6A-D in Supplementary Material). Cells from the highly multifunctional $\mathrm{CD}^{+} \mathrm{T}_{\mathrm{EM}}$ cluster did not demonstrate significant differences in the percentage of CD27 expression between pediatric and adult participants (Figure 7A). However, there was a trend toward higher Ki67 expression in adult participants compared to children ( $p=0.07$; Figure $7 \mathbf{A})$. In contrast, significant differences in CD27 and Ki67 expression levels were observed between children and adults in cells from the highly multifunctional $\mathrm{CD} 8^{+}$ $\mathrm{T}_{\text {EMRA }}$ node (Figure 7B). Canonically, highly differentiated $\mathrm{T}_{\mathrm{EMRA}}$ are thought of as being less proliferative $\left(\mathrm{Ki}^{+} 7^{+}\right)$and more cytotoxic and multifunctional $\left(\mathrm{CD} 27^{-}\right)(30,36)$. However, our data show that SEB stimulation can induce high levels of proliferation among cytotoxic CD27- $\mathrm{T}_{\mathrm{EMRA}}$ in adults, while $\mathrm{T}_{\mathrm{EMRA}}$ in children retain a more naive-like state $\left(\mathrm{CD} 27^{+}\right)$.

Additionally, in order to normalize the observed phenotypes based on their presence within the total sampled memory populations ( $\mathrm{T}_{\mathrm{EM}}$ or $\left.\mathrm{T}_{\mathrm{EMRA}}\right)$, we represented the total number of events from within the highly multifunctional clusters as a percentage of the total memory population sampled by CITRUS before 
clustering. These data confirmed our previous observations from CITRUS analyses that the pediatric participants exhibited a lower proportion of highly multifunctional $\mathrm{CD}^{+} \mathrm{T}_{\mathrm{EM}}$ and $\mathrm{T}_{\mathrm{EMRA}}$, compared to adults (Figures 6C,G). Further, we observed significantly higher total percentages of proliferative $\left(\mathrm{Ki} 67^{+}\right)$, cytotoxic $\left(\mathrm{CD} 27^{-}\right)$, and more naive $\left(\mathrm{CD} 27^{+}\right)$phenotypes among the total activated $\mathrm{CD}^{+} \mathrm{T}_{\mathrm{EM}}$ and $\mathrm{T}_{\mathrm{EMRA}}$ populations in adult participants as compared to children (Figures 7C,D), indicative of the observation that events from within the multifunctional nodes are predominately made up of cells from adults.

\section{DISCUSSION}

Cell-mediated immune responses in healthy pediatric populations are a critical, yet underexplored, area of research, especially among school-aged children. SEB, a mediator of non-menstrual TSS, stimulates a robust, non-clonally specific, multifunctional $\mathrm{T}$ cell immune response in adult PBMC. In this study, we analyzed SEB-stimulated PBMC to better understand similarities and differences in the magnitude and functionality of pediatric and adult $\mathrm{T}$ cell responses.

$\mathrm{T}$ cell subset and memory population analyses are among the limited data sets available in pediatric samples. Previous publications have described an age-dependent increase among the proportion of $\mathrm{CD}^{+}$helper $\mathrm{T}$ cells $(8,9)$. Further, a greater proportion of naive $\mathrm{T}$ cells, and a lesser proportion of effector memory $\mathrm{T}$ cells, has been widely observed in children in both the lymphatic and circulatory systems (11). Our study reaffirms these findings among children and adults, even within a pediatric cohort that reaches into the mid-teenage years.

$\mathrm{T}$ cell activation, as defined by CD69 expression, occurs following engagement of the TCR and a costimulatory molecule. Superantigens such as SEB can engage both the TCR and CD28 homodimer as well as MHC class II molecules $(1,2)$, and are thus capable of inducing robust $\mathrm{T}$ cell activation. In this study, we show net CD69 expression of around 25\% in both $\mathrm{CD}^{+}$and $\mathrm{CD}^{+}$adult peripheral $\mathrm{T}$ cells following SEB-stimulation, consistent with previous reports on non-clonal specific peripheral $\mathrm{T}$ cell activation (1-4). Interestingly, we show $\mathrm{T}$ cell activation in response to SEB to be age-dependent, with levels of net CD69 expression increasing to adult levels as children reach their midto late-teens.

T cell effector functions are diverse, including functions such as cytoxicity against infected targets, as well as recruitment, activation, and proliferation of many cell subsets (37). Superantigens can cause a dangerous and overwhelming proinflammatory $\mathrm{T}$ cell response that causes severe, sometimes fatal disease (3-6). Our data show that individual SEB-stimulated net CD8 ${ }^{+} \mathrm{T}$ effector memory responses are significantly higher in late-teens and adulthood than in younger pediatric participants. These age-related trends were not as strong regarding $\mathrm{CD} 4^{+}$effector memory responses. Interestingly, increases in net multifunctional $\mathrm{T}$ cell responses among both effector memory $\mathrm{CD} 4^{+}$and $\mathrm{CD} 8^{+}$ cells were significantly correlated with age, with younger volunteers showing lower multifunctionality which increases through mid- to late-teenage years, before reaching adult levels. The significant increase of multifunctional $\mathrm{T}$ cells and $\mathrm{CD} 8^{+}$effectors in adults following SEB stimulation suggests a greater likelihood for the TSS-associated cytokine storm among adults compared to children, although the mechanism for these differences remains unclear.

Circulating $\mathrm{T}_{\mathrm{FH}}$ are defined by CXCR5 expression. Although CXCR5 is expressed by activated $\mathrm{CD} 4^{+} \mathrm{T}$ cells, SEB stimulation has shown to be a poor inducer of CXCR5 expression (38), which we have confirmed in the present study. Interestingly, we show that aging through adulthood is significantly correlated with decreasing percentages of $\mathrm{cT}_{\mathrm{FH}}$. In contrast, the percentages of effector $\mathrm{cT}_{\mathrm{FH}}$ appear to increase throughout life. $\mathrm{SEB}$-stimulation does not seem to play a significant role in the induction of activated $\mathrm{cT}_{\mathrm{FH}}$, although it is able to stimulate effector responses within the activated $\mathrm{cT}_{\mathrm{FH}}$ population. The only $\mathrm{cT}_{\mathrm{FH}}$ effector function we observed to be strictly age related was IL-21 production, which has been shown to be important for induction of $\mathrm{T}_{\mathrm{H}} 2$ - and $\mathrm{T}_{\mathrm{H}} 17$-associated immunoglobulin production following SEB stimulation (38). However, because the present study did not explore antibody responses to SEB stimulation among our participants, it is not possible to confirm these previously described findings.

Studies have shown that gender is an important contributing factor to immune variation in both children and adults (39), although the mechanisms behind these differences remain underexplored. Our data show higher $\mathrm{CD}^{+}$effector memory inflammatory cytokines in pediatric males, but few differences in $\mathrm{CD}^{+}$ responses or $\mathrm{CD}^{+} / \mathrm{CD}^{+} \mathrm{T}$ cell multifunctionality, following SEB stimulation. There were no significant differences in activation, defined by CD69 expression, between genders in any age strata. Further, no gender-associated differences were observed among $\mathrm{cT}_{\mathrm{FH}}$ responses. Adult gender-associated human CMI studies have shown higher total $\mathrm{T}$ cell percentages in males and greater $\mathrm{T}$ cell activation $\left(\mathrm{CD}^{\circ} 9^{+}\right)$in females following PHA-stimulation (40), as well as stronger cytotoxic transcriptional T cell responses in women after PHA stimulation followed by PMA-ionomycin restimulation $(41,42)$. Interestingly, our SEB-stimulated data did not recapitulate these observations among our equivalent-sized adult cohort. This heterogeneity among gender-associated $\mathrm{T}$ cell immune responses to various stimulation conditions is beyond the scope of this study, but merits further investigation, especially among more canonical antigen presentation models.

Dimensionality reduction tools are becoming more important in cytometric analysis, as the number of observable parameters within an individual experiment continues to increase. We have shown that CITRUS was able, without bias, to confirm and extend previously observed differences in the proportion of highly multifunctional responses between pediatric and adult participants. Further, we performed downstream analyses to evaluate cell activation and proliferative states in highly multifunctional subsets uncovered in our CITRUS analyses. These data confirmed previous results in adults showing that the proportion of CD27cells is higher in $\mathrm{CD}^{+} \mathrm{T}_{\mathrm{EMRA}}$ than in $\mathrm{T}_{\mathrm{EM}}$ (30). Additionally, our results showed that SEB stimulation can induce strong proliferation among these cytotoxic, more terminally differentiated adult $\mathrm{CD}^{+} \mathrm{T}_{\text {EMRA }}$, a population which is much less frequent in children. Dimensionality reduction allows for a more thorough probing of 
multivariate data, potentially uncovering trends that would otherwise be overlooked. CITRUS and/or other such dimensionality reduction tools need to be included in future studies directed to study multiple functions simultaneously.

Taken together, these findings support the notion that age, rather than gender, strongly influence the magnitude and functionality of SEB-stimulated $\mathrm{T}$ cell responses. Moreover, lower $\mathrm{T}$ cell activation in younger participants may intimate a possible mechanism for lower TSS-associated mortality in children compared to adults (7), and merits further investigation using clinical specimens from TSS patients. Finally, the data included in this manuscript suggest a critical need for in-depth comparisons of pediatric and adult $\mathrm{T}$ cell responses to MHC-restricted antigens. Understanding the variation within canonical immune responses in children and adults could play an important role in guiding the development of new, effective, vaccines designed for children.

\section{ETHICS STATEMENT}

Peripheral blood mononuclear cell were collected from 20 healthy pediatric (6-17 years of age at the time of enrollment) and 14 healthy adult (20-65 years of age at the time of enrollment) volunteers, being recruited from the Baltimore-Washington area and the University of Maryland at Baltimore campus. These studies were approved by the University of Maryland at Baltimore Institutional Review Board (IRB) and were carried out in accordance with the Declaration of Helsinki. Written informed consent was obtained from all adult participants, as well as written assent and informed consent from the parents of any participant under

\section{REFERENCES}

1. Li H, Llera A, Malchiodi EL, Mariuzza RA. The structural basis of T cell activation by superantigens. Annu Rev Immunol (1999) 17:435. doi:10.1146/ annurev.immunol.17.1.435

2. Arad G, Levy R, Nasie I, Hillman D, Rotfogel Z, Barash U, et al. Binding of superantigen toxins into the CD28 homodimer interface is essential for induction of cytokine genes that mediate lethal shock. PLoS Biol (2011) 9:e1001149. doi:10.1371/journal.pbio.1001149

3. Fraser JD. Clarifying the mechanism of superantigen toxicity. PLoS Biol (2011) 9:e1001145. doi:10.1371/journal.pbio.1001145

4. Spaulding AR, Salgado-Pabón W, Kohler PL, Horswill AR, Leung DYM, Schlievert PM. Staphylococcal and streptococcal superantigen exotoxins. Clin Microbiol Rev (2013) 26:422. doi:10.1128/CMR.00104-12

5. Krakauer T, Stiles BG. The staphylococcal enterotoxin (SE) family: SEB and siblings. Virulence (2013) 4:759. doi:10.4161/viru.23905

6. McArthur MA, Sztein MB. Unexpected heterogeneity of multifunctional $\mathrm{T}$ cells in response to superantigen stimulation in humans. Clin Immunol (2013) 146:140. doi:10.1016/j.clim.2012.12.003

7. Chuang YY, Huang YC, Lin TY. Toxic shock syndrome in children: epidemiology, pathogenesis, and management. Paediatr Drugs (2005) 7:11. doi:10.2165/00148581-200507010-00002

8. Tollerud DJ, Ildstad ST, Brown LM, Clark JW, Blattner WA, Mann DL, et al. T-cell subsets in healthy teenagers: transition to the adult phenotype. Clin Immunol Immunopathol (1990) 56:88. doi:10.1016/0090-1229(90)90172-M

9. Saule P, Trauet J, Dutriez V, Lekeux V, Dessaint JP, Labalette M. Accumulation of memory $\mathrm{T}$ cells from childhood to old age: central and effector memory cells in CD4(+) versus effector memory and terminally differentiated memory cells in CD8(+) compartment. Mech Ageing Dev (2006) 127:274. doi:10.1016/j. mad.2005.11.001 the age of 18 years old — and assent from the pediatric participants themselves - prior to the conduct of any study procedures.

\section{AUTHOR CONTRIBUTIONS}

MR, MM, and MS designed the study, analyzed the data and wrote the manuscript; MR performed the experiments; LM aided in the statistical analyses; WC and RB contributed to the design, collected and processed the clinical samples, and helped draft the manuscript.

\section{ACKNOWLEDGMENTS}

We are indebted to the volunteers who allowed us to perform this study. We also thank Ms. Regina Harley, Paula Bernal and Catherine Storrer for excellent technical assistance. This work was supported, in part, by NIAID, NIH, DHHS federal research grants R01 AI036525 and U19 AI082655 [Cooperative Center for Human Immunology (CCHI)] to MBS. The content is solely the responsibility of the authors and does not necessarily represent the official views of the National Institute of Allergy and Infectious Diseases, or the National Institutes of Health.

\section{SUPPLEMENTARY MATERIAL}

The Supplementary Material for this article can be found online at https://www.frontiersin.org/articles/10.3389/fimmu.2018.00498/ full\#supplementary-material.
10. van Gent R, van Tilburg CM, Nibbelke EE, Otto SA, Gaiser JF, JanssensKorpela PL, et al. Refined characterization and reference values of the pediatric T- and B-cell compartments. Clin Immunol (2009) 133:95. doi:10.1016/j. clim.2009.05.020

11. Thome JJ, Yudanin N, Ohmura Y, Kubota M, Grinshpun B, Sathaliyawala T, et al. Spatial map of human $\mathrm{T}$ cell compartmentalization and maintenance over decades of life. Cell (2014) 159:814. doi:10.1016/j.cell.2014.10.026

12. Britanova OV, Putintseva EV, Shugay M, Merzlyak EM, Turchaninova MA, Staroverov DB, et al. Age-related decrease in TCR repertoire diversity measured with deep and normalized sequence profiling. J Immunol (2014) 192:2689. doi:10.4049/jimmunol.1302064

13. Upham JW, Lee PT, Holt BJ, Heaton T, Prescott SL, Sharp MJ, et al. Development of interleukin-12-producing capacity throughout childhood. Infect Immun (2002) 70:6583. doi:10.1128/IAI.70.12.6583-6588.2002

14. Prendergast AJ, Klenerman P, Goulder PJ. The impact of differential antiviral immunity in children and adults. Nat Rev Immunol (2012) 12:636. doi:10.1038/ nri3277

15. Arvin A, Gershon A. Control of varicella: why is a two-dose schedule necessary? Pediatr Infect Dis J (2006) 25:475. doi:10.1097/01.inf.0000219484.55858. a2

16. Watson B. Humoral and cell-mediated immune responses in children and adults after 1 and 2 doses of varicella vaccine. J Infect Dis (2008) 197:S143-6. doi:10.1086/522130

17. Arifuzzaman M, Rashu R, Leung DT, Hosen MI, Bhuiyan TR, Bhuiyan MS, et al. Antigen-specific memory $\mathrm{T}$ cell responses after vaccination with an oral killed cholera vaccine in Bangladeshi children and comparison to responses in patients with naturally acquired cholera. Clin Vaccine Immunol (2012) 19:1304. doi:10.1128/CVI.00196-12

18. Booth JS, Toapanta FR, Salerno-Goncalves R, Patil S, Kader HA, Safta AM, et al. Characterization and functional properties of gastric tissue-resident 
memory T cells from children, adults, and the elderly. Front Immunol (2014) 5:294. doi:10.3389/fimmu.2014.00294

19. Darrah PA, Patel DT, De Luca PM, Lindsay RW, Davey DF, Flynn BJ, et al. Multifunctional TH1 cells define a correlate of vaccine-mediated protection against Leishmania major. Nat Med (2007) 13:843. doi:10.1038/nm1592

20. Kannanganat S, Ibegbu C, Chennareddi L, Robinson HL, Amara RR. Multiple-cytokine-producing antiviral CD4 T cells are functionally superior to single-cytokine-producing cells. J Virol (2007) 81:8468. doi:10.1128/ JVI.00228-07

21. Kannanganat S, Kapogiannis BG, Ibegbu C, Chennareddi L, Goepfert P, Robinson HL, et al. Human immunodeficiency virus type 1 controllers but not noncontrollers maintain CD4 T cells coexpressing three cytokines. J Virol (2007) 81:12071. doi:10.1128/JVI.01261-07

22. Fresnay S, McArthur MA, Magder L, Darton TC, Jones C, Waddington CS, et al. Salmonella Typhi-specific multifunctional CD8+ T cells play a dominant role in protection from typhoid fever in humans. J Transl Med (2016) 14:62. doi:10.1186/s12967-016-0819-7

23. Van Epps P, Banks R, Aung H, Betts MR, Canaday DH. Age-related differences in polyfunctional T cell responses. Immun Ageing (2014) 11:14. doi:10.1186/1742-4933-11-14

24. Sztein MB, Wasserman SS, Tacket CO, Edelman R, Hone D, Lindberg AA, et al. Cytokine production patterns and lymphoproliferative responses in volunteers orally immunized with attenuated vaccine strains of Salmonella typhi. J Infect Dis (1994) 170:1508. doi:10.1093/infdis/170.6.1508

25. Sztein MB, Tanner MK, Polotsky Y, Orenstein JM, Levine MM. Cytotoxic $\mathrm{T}$ lymphocytes after oral immunization with attenuated vaccine strains of Salmonella typhi in humans. J Immunol (1995) 155:3987.

26. McArthur MA, Chen WH, Magder L, Levine MM, Sztein MB. Impact of $\mathrm{CD} 4+\mathrm{T}$ cell responses on clinical outcome following oral administration of wild-type enterotoxigenic Escherichia coli in humans. PLoS Negl Trop Dis (2017) 11:e0005291. doi:10.1371/journal.pntd.0005291

27. Sallusto F, Lenig D, Förster R, Lipp M, Lanzavecchia A. Two subsets of memory $\mathrm{T}$ lymphocytes with distinct homing potentials and effector functions. Nature (1999) 401:708. doi:10.1038/44385

28. Fülöp T, Larbi A, Pawelec G. Human T cell aging and the impact of persistent viral infections. Front Immunol (2013) 4:271. doi:10.3389/fimmu.2013.00271

29. Mahnke YD, Brodie TM, Sallusto F, Roederer M, Lugli E. The who's who of T-cell differentiation: human memory T-cell subsets. Eur J Immunol (2013) 43:2797. doi:10.1002/eji.201343751

30. O'Hara GA, Welten SP, Klenerman P, Arens R. Memory T cell inflation: understanding cause and effect. Trends Immunol (2012) 33:84. doi:10.1016/j. it.2011.11.005

31. Herati RS, Muselman A, Vella L, Bengsch B, Parkhouse K, Del Alcazar D, et al. Successive annual influenza vaccination induces a recurrent oligoclonotypic memory response in circulating $\mathrm{T}$ follicular helper cells. Sci Immunol (2017) 2:eaag2152. doi:10.1126/sciimmunol.aag2152
32. Berglund LJ, Avery DT, Ma CS, Moens L, Deenick EK, Bustamante J, et al. IL-21 signalling via STAT3 primes human naive B cells to respond to IL-2 to enhance their differentiation into plasmablasts. Blood (2013) 122:3940-50. doi:10.1182/blood-2013-06-506865

33. Tangye SG, Ma CS, Brink R, Deenick EK. The good, the bad and the ugly TFH cells in human health and disease. Nat Rev Immunol (2013) 13:412-26. doi:10.1038/nri3447

34. Xu Z, Zan H, Pone EJ, Mai T, Casali P. Immunoglobulin class-switch DNA recombination: induction, targeting and beyond. Nat Rev Immunol (2012) 12:517-31. doi:10.1038/nri3216

35. Bruggner RV, Bodenmiller B, Dill DL, Tibshirani RJ, Nolan GP. Automated identification of stratifying signatures in cellular subpopulations. Proc Natl Acad Sci U S A (2014) 111:E2770-7. doi:10.1073/pnas.1408792111

36. Gerdes J, Lemke H, Baisch H, Wacker HH, Schwab U, Stein H. Cell cycle analysis of a cell proliferation-associated human nuclear antigen defined by the monoclonal antibody Ki-67. J Immunol (1984) 133:1710.

37. Henson SM, Lanna A, Riddell NE, Franzese O, Macaulay R, Griffiths SJ, et al. p38 signaling inhibits mTORC1-independent autophagy in senescent human CD8(+) T cells. JClin Invest (2014) 124:4004. doi:10.1172/ JCI75051

38. Murphy K, Weaver C. Janeway's Immunobiology. 9th ed. (Chap. 9). New York, NY: Garland Science/Taylor \& Francis Group, LLC (2016). p. 345-421.

39. Morita R, Schmitt N, Bentebibel SE, Ranganathan R, Bourdery L, Zurawski G, et al. Human blood CXCR5+CD4+ T cells are counterparts of T follicular cells and contain specific subsets that differentially support antibody secretion. Immunity (2011) 34:108. doi:10.1016/j.immuni.2010.12.012

40. Klein SL, Flanagan KL. Sex differences in immune responses. Nat Rev Immunol (2016) 16:626. doi:10.1038/nri.2016.90

41. Abdullah M, Chai PS, Chong MY, Tohit ER, Ramasamy R, Pei CP, et al. Gender effect on in vitro lymphocyte subset levels of healthy individuals. Cell Immunol (2012) 272:214. doi:10.1016/j.cellimm.2011.10.009

42. Hewagama A, Patel D, Yarlagadda S, Strickland FM, Richardson BC. Stronger inflammatory/cytotoxic T-cell response in women identified by microarray analysis. Genes Immun (2009) 10:509. doi:10.1038/gene.2009.12

Conflict of Interest Statement: The authors declare that the research was conducted in the absence of any commercial or financial relationships that could be construed as a potential conflict of interest.

Copyright $\odot 2018$ Rudolph, McArthur, Barnes, Magder, Chen and Sztein. This is an open-access article distributed under the terms of the Creative Commons Attribution License (CC BY). The use, distribution or reproduction in other forums is permitted, provided the original author(s) and the copyright owner are credited and that the original publication in this journal is cited, in accordance with accepted academic practice. No use, distribution or reproduction is permitted which does not comply with these terms. 